\title{
Pelatihan Peningkatan Kompetensi Mengajar Bagi Petugas Lembaga Pembinaan Khusus Anak (LPKA) Tangerang, Banten
}

\author{
Elizar Ayu Putri ${ }^{1 *}$, Eko Hariyanto², Thomas Sunaryo ${ }^{3}$, Ciek Julyanti Hisyam ${ }^{4}$ \\ ${ }^{1}$ Email: elizarayu@ui.ac.id \\ Universitas Indonesia \\ 2Email: eko.hariyanto65@gmail.com \\ Universitas Indonesia \\ ${ }^{3}$ Email: thomas.sunaryo@gmail.com \\ Universitas Indonesia \\ ${ }^{4}$ Email:ciek_jh@yahoo.co.id \\ Universitas Negeri Jakarta \\ *Correspondence: Email: elizarayu@ui.ac.id
}

\begin{abstract}
Abstrak. Setiap anak, termasuk narapidana anak, memiliki hak atas pendidikan yang bermutu yang dijamin baik oleh Resolusi dan Konvensi yang ditetapkan PBB maupun UUD 1945 amandemen keempat. Pemenuhan hak atas pendidikan bagi narapidana anak juga merupakan bagian dari pembinaan agar narapidana anak dapat kembali ke masyarakat dan menjadi warga negara yang taat hukum dan bertanggung jawab. LPKA Tangerang sebagai UPT di bawah Kementerian Hukum dan HAM di wilayah Provinsi Banten menjalankan tugas dan fungsi pembinaan terhadap narapidana anak. Salah satunya adalah penyelenggaraan pendidikan formal dan non-formal bagi narapidana anak yang menjadi binaannya. Berbagai penelitian menemukan bahwa penyelenggaraan pendidikan di LPKA Tangerang berjalan seadanya, tidak berkelanjutan, dan belum sepenuhnya dapat mengakomodir minat dan bakat serta kebutuhan narapidana anak, serta masih jauh tertinggal dari sekolah-sekolah di luar tembok penjara. Salah satu kendala utamanya adalah rendahnya kompetensi guru yang mengajar. Para guru di LPKA Tangerang umumnya adalah para petugas LPKA yang tidak memiliki latar belakang pendidikan guru. Oleh karena itu, sangat diperlukan adanya pelatihan dan pendampingan teknologi pembelajaran bagi para guru di LPKA Tangerang. Melalui kegiatan ini, diharapkan adanya peningkatan kompetensi pembelajaran bagi para guru di LPKA tersebut, sehingga pada gilirannya nanti akan dapat meningkatkan kualitas pendidikan bagi narapidana anak di LPKA tersebut.
\end{abstract}

Kata Kunci: Pendidikan, Hak Anak, Hak Narapidana, Pembinaan

DOI: http://dx.doi.org/10.35914/tomaega.v3i1.304

Article history:

Received January 18, 2020; Revised January 23, 2020; Accepted January 31, 2020

\section{PENDAHULUAN}

Pengabdian kepada masyarakat (PKM) oleh Tim Pengabdi Departemen Kriminologi Universitas Indonesia ini dilaksanakan di Lembaga Pembinaan Khusus Anak (LPKA) Tangerang-Banten. Kegiatan PKM ini merupakan aksi nyata yang dilakukan oleh Tim Pengabdi sebagai tindak lanjut atas hasil penelitian yang dilakukan pada tahun 2014 sampai dengan 2017 yang dilakukan di beberapa LPKA, termasuk LPKA Tangerang. Kegiatan PKM 
ini didanai sepenuhnya oleh Direktorat Riset dan Pengabdian Masyarakat (DRPM) Universitas Indonesia pada pertengahan tahun 2019 sebagai wujud kepedulian UI terhadap isu pemenuhan hak anak yang berkonflik dengan hukum.

Kegiatan PKM di LPKA Tangerang ini dilatarbelakangi oleh 3 (tiga) alasan. Alasan pertama adalah bahwa pemenuhan hak atas pendidikan adalah hak asasi bagi setiap orang yang dilindungi dan dijamin oleh Resolusi dan Konvenan yang ditetapkan oleh PBB, seperti Deklarasi Universal Hak Anak (DUHAM), Konvensi Hak Anak (KHA), Deklarasi Wina (1993), dan sebagainya. Selain itu juga dijamin oleh amanat UUD 1945 amandemen keempat, Bab III pasal 31 ayat (1) dan ayat (2) yang berbunyi:

(1) Setiap warga negara berhak mendapat Pendidikan;

(2) Setiap warga negara wajib mengikuti Pendidikan dasar dan pemerintah wajib membiayainya.

Pemenuhan hak warga negara atas pendidikan lebih lanjut dijamin melalui UndangUndang Nomor 20 Tahun 2003 tentang Sistem Pendidikan Nasional pasal 5 ayat 1. Dalam pasal tersebut disebutkan bahwa "Setiap warga negara mempunyai hak yang sama untuk memperoleh pendidikan bermutu". Sementara pada pasal 5 ayat 5 tertulis bahwa "setiap warga negara berhak mendapat kesempatan meningkatkan pendidikan sepanjang hayat".

Alasan kedua, bahwa Pendidikan dan pelatihan bagi narapidana dalam penjara adalah sangat penting dan memiliki dampak positif bagi narapidana dan masyarakat. Terkait dengan dampak positif ini, Halwey, dkk. (2013:9) menyatakan ada beberapa rasionalisasi pentingnya penyediaan pendidikan bagi narapidana, yaitu :

1. Akses kepada pendidikan dan pelatihan adalah hak setiap orang;

2. Menurunkan biaya atau kerugian akibat kejahatan;

3. Membantu rehabilitasi dan reintegrasi narapidana;

4. Meningkatkan kesempatan kerja bagi narapidana.

Chaves dan Dawe (dalam Dawe, dkk, 2007: 19-20) menyebutkan bahwa penyediaan pendidikan dalam penjara dapat:

5. Menurunkan Residivisme.

Adapun Elizabeth G. Hill (2008:4) dalam laporannya mengkaitan dampak positif pendidikan penjara dengan:

6. Meningkatkan Tingkat Pendidikan Narapidana;

7. Meningkatkan Manajemen Penjara; dan

8. Memberi Manfaat Fiskal Bagi Pemerintah.

Sedangkan dalam prisonstudiesproject.org disebutkan bahwa pendidikan dalam penjara dapat:

9. Menurunkan Pelanggaran Dalam Penjara; dan

10. Memiliki Efek Positif Terhadap Anak yang Orang Tuanya Dipenjara. 
Hal senada juga dilaporkan oleh UNESCO (1995:33-37) yang menyatakan bahwa berbagai riset di berbagai negara seperti Australia, Botswana, Kanada, Cina, Mesir, Perancis, Hongkong, Inggris dan Amerika Serikat membuktikan bahwa terdapat indikasi kuat bahwa pendidikan khususnya vokasional, memiliki dampak positif terhadap residivisme dan bukti reintegrasi sosial narapidana yang berhasil.

Lebih lanjut Halwey dkk (2013:9-120) mengemukakan bahwa:

Pendidikan dapat membantu menanamkan perasaan pada narapidana bahwa mereka masih merupakan bagian dari komunitas dan mengingatkan mereka bahwa mereka akan tetap menjadi bagian dari masyarakat setelah mereka bebas.... Mendukung narapidana dalam mencari pengetahuan, keterampilan dan kompetensi membentuk batu pijakan penting dalam perjalanan mereka menuju rehabilitasi dan reintegrasi dalam masyarakat.... Secara umum, terdapat suatu bukti bahwa pendidikan dan pelatihan membantu dalam pengembangan modal sosial.

Alasan ketiga adalah bahwa berbagai hasil penelitian (lihat Hariyanto, dkk. 2014; juga Lolo, 2016; Budi, 2010; Baifri, 2007; Tamtomo, 2007; Kumalasari, 2005; Mardiyati, 2005; Riyadi, 2005; dan Yatiman, 2005) menemukan bahwa penyelenggaraan pendidikan formal dan/atau non formal bagi narapidana anak yang berada di dalam LPKA belum berlangsung sebagaimana yang digariskan dalam Standar Nasional Pendidikan. Penyelenggaraan pendidikan di LPKA berjalan seadanya, tidak berkelanjutan, dan belum sepenuhnya dapat mengakomodir minat dan bakat serta kebutuhan narapidana anak, serta masih jauh tertinggal dari sekolah-sekolah di luar tembok penjara. Perihal belum terlaksananya pendidikan layanan khusus yang bermutu bagi narapidana anak yang sedang menjalani pidananya di LPKA diakui oleh pemerintah. Hal tersebut tercermin dalam Rencana Kerja Pemerintah tahun 2015 (BAPENAS, 2014:68) yang menyebutkan bahwa "anak yang berada di LAPAS (termasuk LPKA - pen.) masih mengalami kendala dalam mengakses layanan pendidikan". Realitas ini jelas merupakan masalah sosial yang sangat serius dan sekaligus merupakan pelanggaran hak asasi manusia, khususnya hak atas pendidikan yang bermutu, sehingga sangat mendesak untuk segara diupayakan penanganannya.

Sehingga sangatlah tepat kebijakan pemerintah yang tertuang dalam Rencana Kerja Pemerintah tahun 2015 (BAPENAS, 2014:68) yang menetapkan bahwa:

$\underline{\text { Tantangan ke depan di bidang pendidikan adalah meningkatkan akses dan kualitas }}$ layanan kelangsungan hidup dan tumbuh kembang anak, termasuk akses anak dengan kondisi khusus (termasuk di dalamnya narapidana anak - pen.) terhadap layanan yang dibutuhkan (yakni layanan pendidikan—pen).

Salah satu upaya untuk meningkatkan akses dan kualitas layanan pendidikan bagi narapidana anak di LPKA adalah dengan meningkatkan jumlah SDM guru/tutor yang kompeten. Karena para guru/tutor yang mengajar di LPKA umumnya adalah para petugas LPKA tersebut yang notabene tidak memiliki latar belakang pendidikan ilmu keguruan dan kependidikan, sehingga mereka umumnya tidak memiliki kompetensi untuk mengajar dan 
menjadi guru. Padahal, menurut Sanjaya (2006), keberhasilan pelaksanaan proses pendidikan sangat bergantung pada guru sebagai ujung tombak. Sebagaimana bagus dan idealnya kurikulum pendidikan, seberapa lengkap sarana dan prasarana pendidikan, tanpa diimbangi dengan kemampuan guru dalam mengimplementasikan, maka semua itu tidak ada artinya. Melihat pada permasalahan ini, maka upaya yang sangat mendesak untuk segera dilakukan dalam rangka perbaikan dan peningkatan kualitas pendidikan bagi narapidana anak di LPKA Tangerang adalah meningkatkan kapasitas atau kompetensi guru dalam proses pembelajaran yang ada di LPKA Tangerang.

Salah satu cara yang dapat dilakukan untuk meningkatkan jumlah guru/tutor yang kompeten adalah melalui pelatihan dan pendampingan terhadap para petugas LPKA tersebut, khususnya yang terkait dengan teknik atau metode pembelajaran yang meliputi kurikulum, Rencana Pelaksanaan Pembelajaran (RPP), media pembelajaran (alat peraga), metode pembelajaran, dan evaluasi hasil belajar. Untuk maksud dan tujuan tersebut kegiatan PKM ini dilaksanakan.

\section{METODE}

Kegiatan pengabdian kepada masyarakat (PKM) ini dilakukan di LPKA Tangerang, Kota Tangerang, Provinsi Banten. Sasaran kegiatan ini adalah para petugas LPKA yang mengajar di sekolah-sekolah formal pada jenjang Sekolah Dasar, Sekolah Menengah Pertama, dan Sekolah Menengah Kejuruan yang dikelola oleh LPKA tersebut.

Metode yang digunakan dalam kegiatan PKM adalah in-house training dan pendampingan. Metode ini dipilih karena Tim Pengabdi menganggap metode ini tepat untuk mengatasi permasalahan rendahnya kompetensi para guru di LPKA Tangerang karena beberapa alasan, yakni:

a. Metode pelatihan dan pendampingan ini jauh lebih mudah, cepat, dan ekonomis dibandingkan dengan upaya lain, seperti menyekolahkan para guru ke universitas atau akademi keguruan dan kependidikan selama beberapa tahun;

b. Waktu pelaksanaan pelatihan dan pendampingan lebih fleksibel, sehingga data disesuaikan dengan jadwal kerja dan beban tugas para petugas LPKA karena pelaksanaan pelatihan dan pendampingan diadakan di lingkungan LPKA Tangerang;

Program pelatihan dan pendampingan ini difokuskan pada peningkatan kompetensi dasar para guru di LPKA Tangerang. Tim Pengabdi merancang lima materi utama yang menjadi kompetensi dasar para guru di LPKA Tangerang. Kelima materi dan kompetensi dasar tersebut dapat dilihat pada Tabel 1 berikut. 
Tabel 1. Materi Pelatihan dan Kompetensi Guru

\begin{tabular}{|c|c|c|}
\hline No. & Materi Pelatihan & Kompetensi Guru \\
\hline 1 & $\begin{array}{llr}\text { a. } & \text { Kurikulum } & \\
& \text { (KURTILAS) } \\
\text { b. Standar kompetensi lulusan } \\
\text { Pendidikan Dasar dan } \\
\text { Menengah } \\
\text { c. Standar Isi untuk program } \\
\text { kejar Paket A, B, dan C }\end{array}$ & 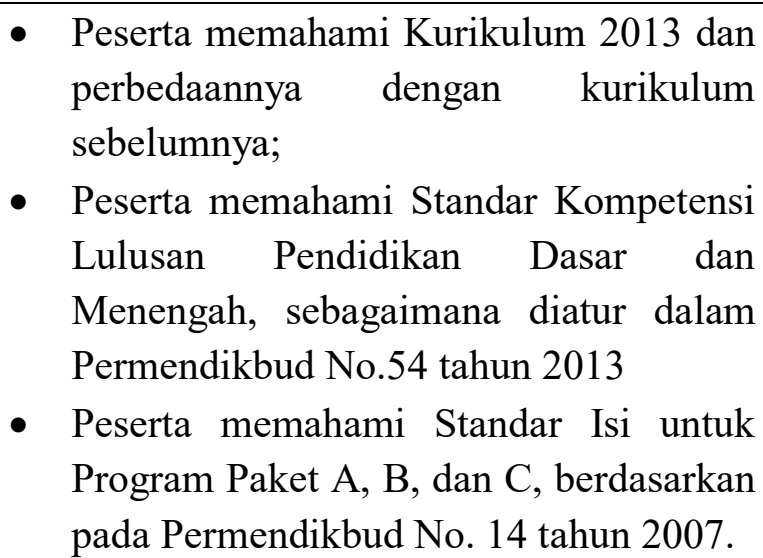 \\
\hline 2 & $\begin{array}{llr}\text { a. } & \text { Model-model } & \text { pembelajaran } \\
\text { yang efektif } & \\
\text { b. Pembelajaran } & \text { berbasis } \\
\text { kontekstual } & \end{array}$ & $\begin{array}{l}\text { - Peserta mampu memilih dan } \\
\text { menerapkan model pembelajaran yang } \\
\text { dianggap efektif, dan tepat dengan } \\
\text { kondisi anak didiknya. }\end{array}$ \\
\hline 3 & $\begin{array}{l}\text { Penyusunan Rencana } \\
\text { Pelaksanaan Pembelajaran (RPP) }\end{array}$ & 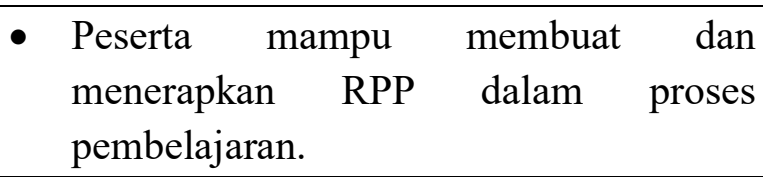 \\
\hline 4 & $\begin{array}{ll}\text { Media } & \text { Pembelajaran } \\
\text { Peraga) } & \end{array}$ & $\begin{array}{l}\text { - Peserta mampu membuat dan } \\
\text { menggunakan media pembelajaran } \\
\text { dalam proses pembelajaran. }\end{array}$ \\
\hline 5 & $\begin{array}{l}\text { Evaluasi Proses dan } \\
\text { Pembelajaran }\end{array}$ & $\begin{array}{l}\text { - Peserta mampu membuat soal untuk tes; } \\
\text { - Peserta mampu menganalisis hasil tes; } \\
\text { - Peserta dapat mengolah dan menetapkan } \\
\text { nilai berdasarkan pada hasil tes anak } \\
\text { didiknya. }\end{array}$ \\
\hline
\end{tabular}

Setelah mengikuti pelatihan dan pendampingan, para guru di LPKA Tangerang yang terdiri atas petugas LPKA dan tutor diharapkan memiliki pengetahuan dan keterampilan dalam proses pembelajaran yang dapat diterapkan saat mengajar di sekolah formal dan non formal di LPKA Tangerang. Tidak hanya itu, para guru di LPKA Tangerang juga diharapkan mampu memahami dan menerapkan ilmu pengetahuan dan teknologi yang menunjang pembelajaran terkini.

Berikut adalah diagram proses pelaksanaan kegiatan pelatihan dan pendampingan peningkatan kompetensi mengajar bagi para petugas LPKA Tangerang: 


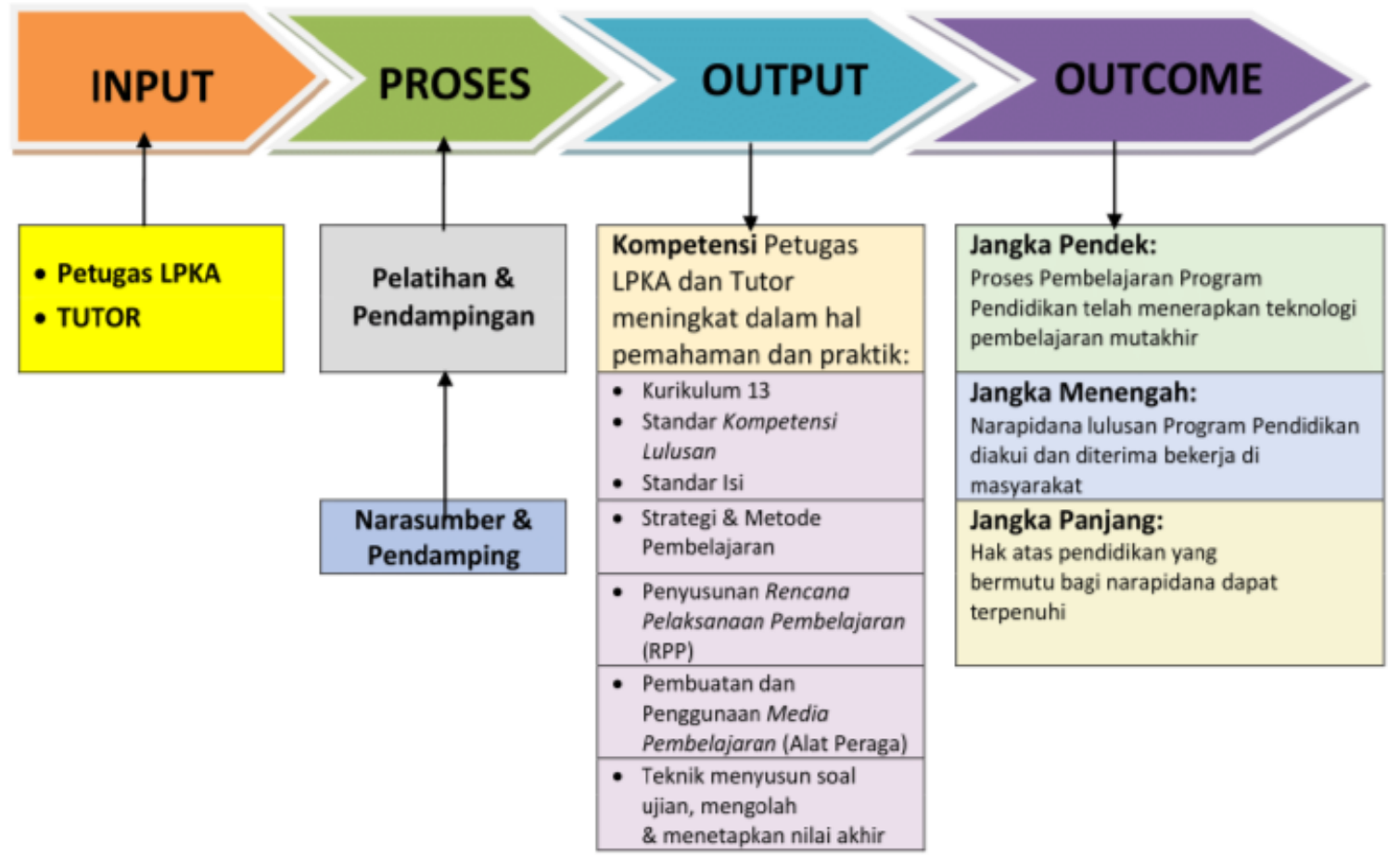

Gambar 1. Diagram Proses: Input-Proses-Output-Outcome

\section{HASIL DAN PEMBAHASAN}

\section{a. Deskripsi Kegiatan Pelatihan dan Pendampingan Guru di LPKA Tangerang}

Pelaksanaan kegiatan pelatihan dan pendampingan dibagi menjadi dua tahap, yakni tahap pembekalan materi dan tahap praktik mengajar. Pada tahap pertama, kegiatan pelatihan kompetensi guru di LPKA Tangerang dibagi menjadi empat sesi pelatihan berdasarkan pada 7 materi utama. Adapun ketujuh materi utama pelatihan dapat dilihat pada Tabel 1.

Secara umum penyajian materi pelatihan dapat disajikan dalam bentuk ceramah tatap muka yang berlangsung dua arah dimana narasuber akan menjelaskan materi pelatihan secara rinci (Lihat Gambar 2). Dengan metode ini diharapkan para peserta pelatihan memperoleh pengetahuan awal tentang materi yang dibahas. Setelah itu, narasumber akan membuka sesi tanya jawab untuk memperdalam pemahaman para peserta pelatihan.

Setiap sesi pelatihan dilanjutkan dengan kegiatan praktik oleh para peserta pelatihan. Di sini peserta pelatihan dibagi menjadi beberapa kelompok. Setiap kelompok didampingi oleh seorang pendamping dari Tim Pengabdi dan narasumber. Setiap kelompok diberikan tugas yang dikerjakan di dalam kelas atau di luar jam pelatihan. Peserta diperkenankan berkonsultasi dengan para pendamping apabila mengalami kesulitan dalam pengerjaan tugas praktik tersebut. Tugas praktik akan dikumpulkan dan dibahas pada pelatihan berikutnya dalam forum diskusi kelas. 


\section{TO MAEGA Volume 3 Nomor 1, Februari 2020, hlm : 36-46}

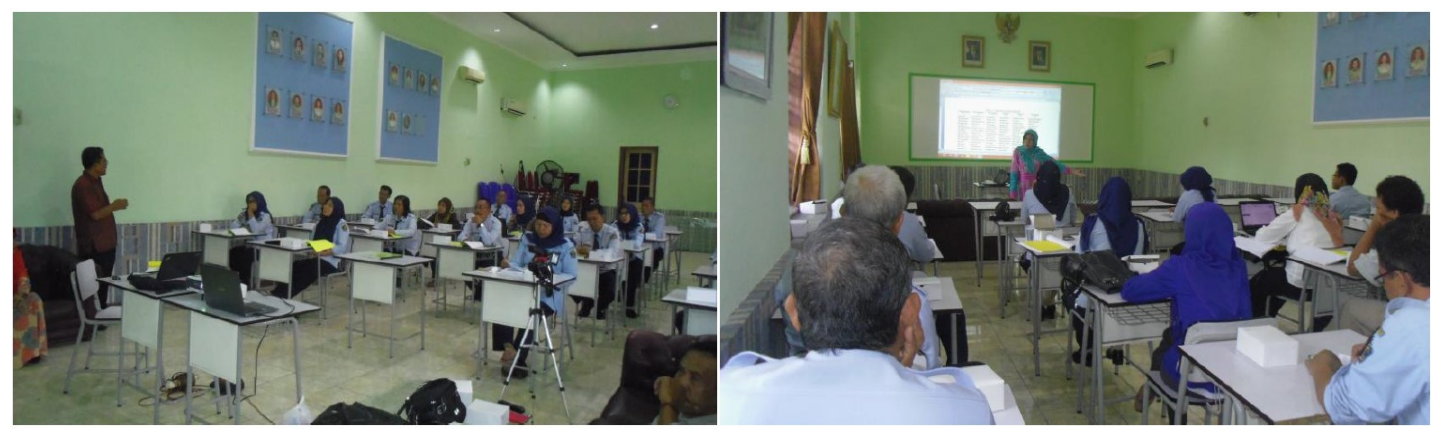

Gambar 2. Penyampaian Materi Secara Tatap Muka

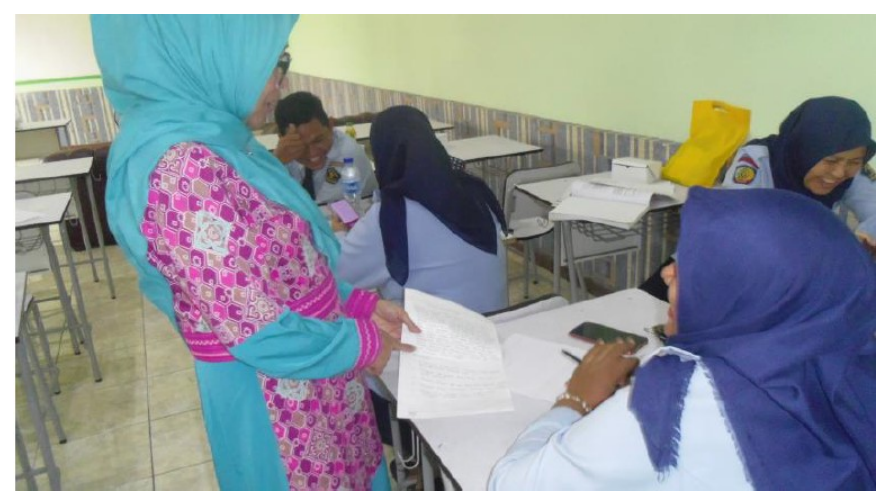

Gambar 3. Kegiatan Praktik Secara Berkelompok

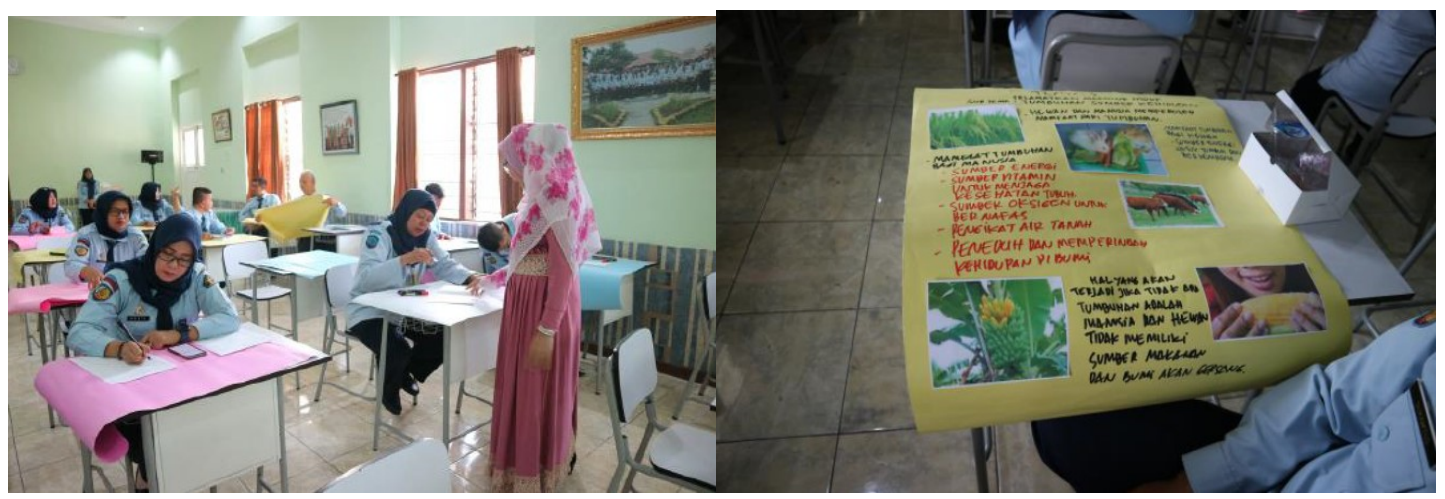

Gambar 4. Kegiatan Membuat Media Pembelajaran

Diskusi kelas merupakan forum untuk mempresentasikan dan mendiskusikan hasil pekerjaan kelompok. Setiap kelompok secara bergantian diminta mempresentasikan hasil tugas kelompoknya. Sedangkan kelompok lain berperan sebagai penyanggah. Selain berguna untuk memperdalam pemahaman tentang suatu materi atau topik, kegiatan diskusi memiliki beberapa kegunaan lain, yaitu:

a. Para peserta dapat belajar mempresentasikan dan mempertahankan pendapatnya secara ilmiah dan santun;

b. Berdiskusi juga melatih para peserta belajar menghargai pendapat orang lain;

c. Melalui diskusi, para peserta juga belajar menyelesaikan suatu masalah atau tugas bersama dengan kelompok. 


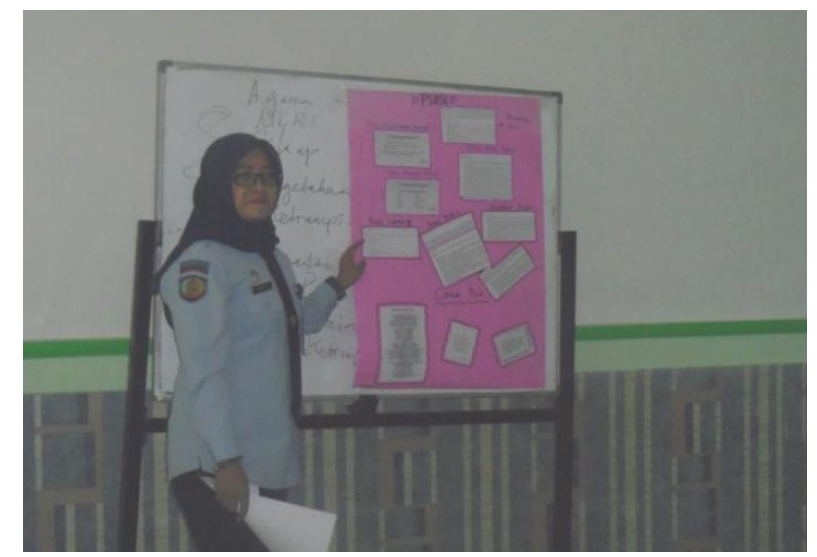

Gambar 6. Praktik Mengajar dengan Menggunakan Alat Peraga Karyanya

Sebelum sesi pelatihan ditutup, biasanya akan dilakukan kegiatan umpan balik. Melalui kegiatan ini diharapkan para peserta memberikan komentar terkait dengan materi dan pelaksanaan pelatihan yang sedang berjalan. Umpan balik ini sangat penting untuk dijadikan masukan dan pedoman dalam evaluasi, revisi, dan penyempurnaan materi dan pelaksanaan pelatihan berikutnya.

Pada tahap kedua, kegiatan dilanjutkan dengan praktik mengajar. Sesi pelatihan ini merupakan lanjutan dari pembekalan materi terkait pengajaran. Para peserta diarahkan untuk mengajar secara riil di kelas yang diampu dengan menerapkan semua pengetahuan dan keterampilan yang diperoleh dari tahap kegiatan pengabdian masyarakat pertama. Pada tahap ini Tim Pengabdi berperan sebagai pendamping bagi para peserta pelatihan.

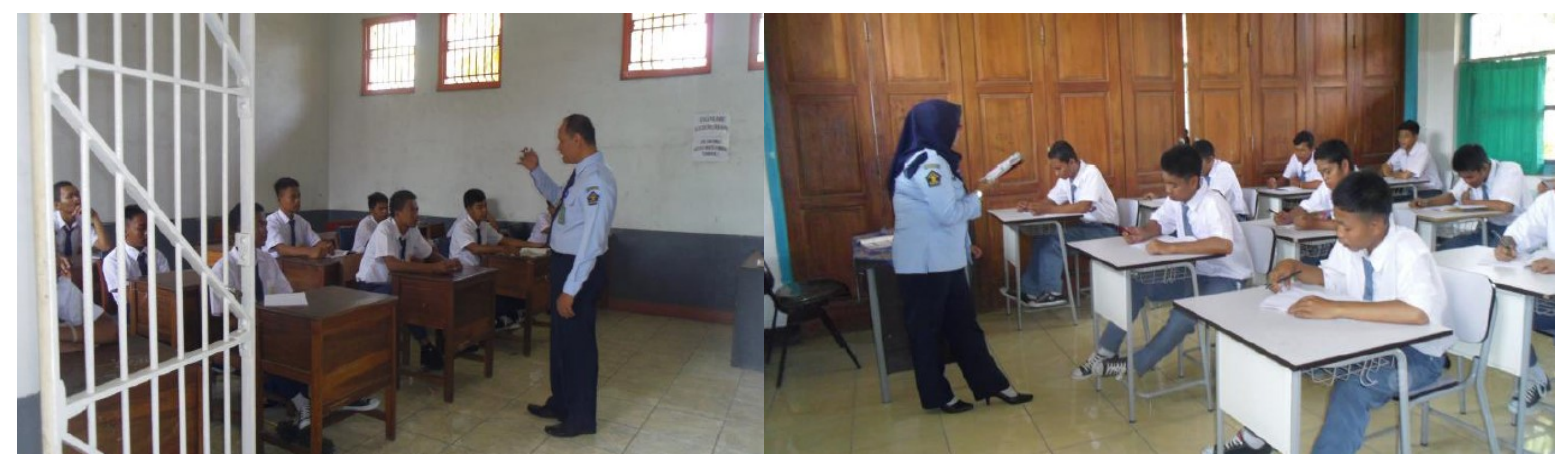

Gambar 7. Peserta Pelatihan Sedang Praktik Mengajar di Kelas

\section{b. Keunggulan Kegiatan Pengabdian Masyarakat}

Kegiatan pengabdian masyarakat LPKA Tangerang berupa in-house training dan pendampingan bagi para guru di LPKA Tangerang memiliki beberapa keunggulan. Pertama, kegiatan pengabdian masyarakat ini secara langsung menargetkan pada aspek krusial yang perlu diperbaiki terlebih dahulu dalam upaya peningkatan kualitas pendidikan, yakni pembenahan kompetensi guru. Kedua, materi yang dirancang untuk pelatihan dan pendampingan disesuaikan dengan kebutuhan riil para guru agar dapat memperoleh kompetensi pedagogik yang sesuai dengan standar yang ditetapkan oleh Kementerian Pendidikan dan Kebudayaan. Ketiga, melalui metode in-house training, pelatihan dan 
pendampingan lebih efektif dan fleksibel dengan jadwal para guru di LPKA Tangerang yang juga merangkap sebagai petugas LPKA.

\section{c. Kendala dalam Kegiatan Pengabdian Masyarakat}

Secara umum pelaksanaan kegiatan pengabdian kepada masyarakat (PKM) di LPKA Tangerang, Banten berjalan dengan lancar. Meski demikian, terdapat beberapa kendala umum yang dihadapi oleh tim pengabdi selama pelaksanaan kegiatan pengabdian kepada masyarakat tersebut, yakni sebagai berikut:

- Waktu pelatihan dan pendampingan yang terbatas

- SDM tutor narapidana pada umumnya tidak memiliki latar belakang sebagai pendidik

- Peserta tidak dapat mengikuti pelatihan secara penuh waktu.

- Terbatasnya buku teks pelajaran dan buku pengayaan, sehingga para peserta mengalami kesulitan dalam praktik menyusun RPP dan praktik mengajar.

- Tidak adanya anggaran untuk pembelian buku paket dan buku pengayaan.

\section{SIMPULAN DAN SARAN}

Pelaksanaan kegiatan pengabdian masyarakat LPKA Tangerang berupa in-house training dan pendampingan bagi para guru di LPKA Tangerang berjalan dengan baik. Para peserta pelatihan mampu menggunakan pengetahuan mengenai kompetensi pedagogik yang diberikan selama pelatihan tahap pertama ketika memberikan pengajaran di kelas. Meski demikian, ditemukan beberapa kendala yang terjadi selama kegiatan dilaksanakan.

Adapun saran dalam pelaksanaan pengabdian masyarakat di LPKA Tangerang, Banten, khususnya terkait dengan pelayanan pendidikan sebagai bagian dari pembinaan bagi narapidana anak, sebagai berikut:

a. Kegiatan pengabdian masyarakat di LPKA maupun LAPAS yang melibatkan petugas sebagai anggota harus menyesuaikan dengan peraturan yang ada. Hal ini dilakukan dengan cara bekerjasama dengan petugas jaga agar peserta dapat dating tepat waktu dan didahulukan absensinya saat apel.

b. Perlu dipersiapkan materi dan metode pelatihan dan pendampingan yang komprehensif, bertahap, dan berkesinambungan, mengingat para peserta pelatihan pada umumnya tidak memiliki latar pendidikan keguruan.

c. Perlunya melibatkan banyak pendamping yang memiliki pengalaman mengajar.

d. Diperlukan adanya buku teks pelajaran yang memadai, sehingga para peserta dapat menyusun Rancangan Pelaksanaan Pembelajaran (RPP) dengan baik.

\section{DAFTAR PUSTAKA}

Baifri, Vivi Sylviani. (2007). Program Pembinaan Bagi Anak Didik Pemasyarakatan Pidana Pendek. Jakarta: Tesis, Program Studi Pengkajian Ketahanan Nasional, Program Pascasarjana-UI.

BAPENAS. (2014). Rencana Kerja Pemerintah tahun 2015. Jakarta: BAPENAS 
Budi, (2010). Pemenuhan Hak Untuk Mendapatkan Pendidikan Bagi Anak Didik Pemasyarakatan Di Rumah Tahanan Negara Jakarta Timur. Jakarta: Tesis, Program Studi Pengkajian Ketahanan Nasional, Program Pascasarjan-UI.

Dawe, Susan (ed). (2007). Vocational Educational and Training for Adult Prisoners and Offenders in Australia: Research Readings, Adelaide: Australian Government.

Halwey, Jo, et al. (2013). Prison Education and Training in Europe: Current State-of-Play and Challenges. GHK Consulting.

Hariyanto, Eko, dkk., (2014) Survey dan Pendataan Tentang Pelaksanaan Program Pendidikan Khusus dan Layanan Khusus Bagi Narapidana Anak di Lembaga Pemasyarakatan (LAPAS) Dalam Rangka Pengembangan Model Implementasi Program Pendidikan Khusus dan Layanan Khusus Bagi Narapidana Anak Yang Sedang Menjalani Masa Hukuman di Lembaga Pemasyarakatan (LAPAS), (Jakarta: Laporan Penelitian, kerjasama Pusat Kajian Kriminologi FISIP-UI, Institute for Criminal Policy Studies dan Direktorat Pendidikan Khusus Layanan Khusus, Direktorat Pendidikan Dasar, Kementerian Pendidikan Nasional, 2014).

Henson, Peter. Employment - The Key to Keeping People Out of Prison. Hill, Elizabeth G., (2008). From Cellblocks to Classrooms: Reforming Inmate Education To Improve Public Safety. Sacramento: The Legislative Analyst's Office (LAO).

Kumalasari, Ratna. (2005). Meningkatkan Kemampuan Petugas Pemasyarakatan Dalam Memotivasi Belajar Anak Didik Di Lapas Anak Pria Tangerang. Jakarta: Tesis, Pascasarjana Psikologi-UI.

Lolo, Ferdinand T. Andi, dkk., (2016). Faktor-Faktor Yang Menghambat Penyelenggaraan Pendidikan Yang Bermutu Bagi Narapidana Anak di LAPAS Untuk Dewasa di Jawa Barat. Depok: Laporan Penelitian Hibah Riset Unggulan FISIP-UI Tahun 2016.

Mardiyati, Veronika (2005). Pemenuhan Hak Pendidikan Bagi Anak Didik Pemasyarakatan di Lembaga Pemasyarakatan Anak (Studi Kasus Anak Didik Pada Lembaga Pemasyarakatan Anak Wanita Tangerang). Jakarta: Tesis, Program Studi Pengkajian Ketahanan Nasional, Program Pascasarjana-UI.

Riyadi, Aman (2005). Manajemen Pendidikan Bagi Anak Didik Pemasyarakatan: Studi Kasus di Lembaga Pemasyarakatan KLas IIA Anak Kutoarjo. Jakarta: Tesis, Program Studi Pengkajian Ketahanan Nasional, Program Pascasarjana-UI.

Sanjaya, Wina. (2006). Pembelajaran dalam Implementasi Kurikulum Berbasis Kompetensi. Jakarta: Penerbit Kencana

Tamtomo, F. Haru. (2007). Penyelenggaraan Pendidikan Khusus Bagi Anak Didik Pemasyarakatan Di Lembaga Pemasyarakatan. Jakarta: Tesis, Program Studi Pengkajian Ketahanan Nasional, Program Pascasarjan-UI.

UNESCO. (1995). Basic Education in Prisons. Baltimore: Maryland State Department of Education. 
To Maega | Jurnal Pengabdian Masyarakat

P-ISSN: 2622-6332 \& E-ISSN: 2622-6340

TO MAEGA Volume 3 Nomor 1, Februari 2020, hlm : 36-46

Undang-Undang nomor 20 Tahun 2003 tentang Sistem Pendidikan Nasional.

Yatiman, Yatiman. (2005). Penyelenggaraan Pendidikan Formal Di Lembaga Pemasyarakatan Anak: Studi Kasus di Lapas Anak Pria Tangerang. Jakarta: Tesis, Program Studi Pengkajian Ketahanan Nasional, Program Pascasarjana-UI. 